\title{
Plagues, Epidemics and Their Social and Economic Impact on the Egyptian Society during the Mameluke Period (648 Hegira /1250 AD -923 Hegira /1517 AD)
}

\author{
Isa Mahmoud Alazzam¹, Sobhi Mahmoud Alazzam² \& Khalid Mahmoud Al-Mazyid ${ }^{3}$ \\ ${ }^{1}$ History and Islamic Civilization, College of Arts and Sciences, Department of Humanities, Jordan University of \\ Science and Technology, Jordan \\ ${ }^{2}$ Islamic History, Faculty Of Arts, Department of History, Mutah Univeristy, Jordan \\ ${ }^{3}$ Department of Basic Sciences, Al-Huson University College, Al-Balqaa Applied University, Jordan \\ Correspondence: Isa Mahmoud Alazzam, History and Islamic Civilization, College of Arts and Sciences, \\ Department of Humanities, Jordan University of Science and Technology, Jordan. Tel: 962-777-763-705. E-mail: \\ isa.alazzam@yahoo.com
}

Received: January 10, 2013 Accepted: February 10, 2013 Online Published: March 22, 2013

doi: 10.5539/ach.v5n2p87 URL: http://dx.doi.org/10.5539/ach.v5n2p87

\begin{abstract}
The study aims at shedding light on plagues and epidemics that hit Egypt during the Mameluke period through describing the plague disease and the plagues and epidemics that hit Egypt and the social and economic impact on the Egyptian society. The study is based on some historical sources that are contemporary of the Mameluke period, especially the book "Al-Suluk li-marifatiduwal Al-muluk" by Al- Maqrizi and we reach the following conclusions through this research:

- Plagues are bacterial and lethal epidemics that spread fast, and have the symptoms of high temperature nausea, and severe fatigue. Most plagues that hit Egypt during the Mameluke era were very severe, and that what is usually referred to as the Great plague or Black Death, where the patient dies within one week of having the disease.

- The plagues had harsh social effects on the population, where it caused the death of individuals, and damaged hundreds of Egyptian villages and cities, The conditions of the society almost came a halt, and were an impetus for the people to bind in social solidarity, and the true repentance to Allah the almighty, and the increase of worship and alms hoping that Allah the almighty will shield the people from this disease.

- The plagues and epidemics led to disorder and disruption of the economic conditions of the society, where most land was left without farming and most trades and crafts were disrupted and earnings hit lows in the markets and trade was in recession in commerce and trade in general.
\end{abstract}

Keywords: plagues, epidemics, Egypt, mameluke, society, disruption, social, economic, disease

\section{Introduction}

The study aims at shedding light on plagues and epidemics that hit Egypt during the Mameluke period through describing the plague disease and the plagues and epidemics that hit Egypt, and their social and economic effects on the Egyptian society, The study is based on some historical sources contemporary of the Mameluke period, especially the book "Al-Suluk li-marifatiduwal Al-muluk" by Al Maqrizi.

\subsection{The Description of the Plague Disease and Epidemics}

The plague is a well-known disease "where the air is polluted, Thus spoiling the moods and the bodies" (Ibn Manzour, 1900) and among the people of medicine "a bad tumor and comes out with it a very painful inflammation that exceeds the limit in that, and the area around it becomes mostly black or (yellow) and blisters fast and in most cases occurs in three areas: in the armpit behind the ear tip of the nose, and the soft flash (Ibn Al Qayyim, 2002).

The cause of the plague as mentioned by Ibn Qayyim Al-Jawziyah "a bad blood that leans towards corruption and putrescence and does not improve and corrupts the organ and may ooze blood and pus ,and spoils the heart 
and causes vomiting, palpitation and syncope" fainting this name Though includes every tumor that leads to the heart and becomes fatal, it is more specific regarding the endocrine flesh, attacking only the weakest organs that take it because it is so corrupt and foul, and the worst that occurs in the armpit and behind the ears because of the proximity to the organs in the head and the least damaging is the one with red color, then the yellow color, as for the one with the black color. No one even escapes that (Ibn Al-Qayyim, 2002).

Every plague is an epidemic but not every epidemic is aplague and since that plague is an epidemic disease, Islam affirmed the necessity that no one enters or leaves the areas where it spreads, The Prophet peace be upon him said: The plague is a wrath, so if you hear that it is in acertain area, do not enter there, and if it occurs in an area while you are there, do not leave that area as an escape, When the prophet, peace be upon him, was asked about the plague he said: a gland like that of a camel that comes out in the hypochondrium and the armpit (Ibn Al-Qayyim, 2002).

We derive from the historical sources that talked about plagues that hit Egypt, that plague is a bacterial epidemic disease of high temperature level and the some of its symptoms are, sharp increase, in temperature, nausea, and severe fatigue (Al-Maqrizi, 1971; Ibn Taghri Bardi, 1992), and acute catarrh that descends from brain to chest (Al-Maqrizi, 1971).

Some of those afflicted with it used to hit the ground with their heads due to severe pain until they die (Al-Maqrizi,1971), and most individuals afflicted with plague usually die within four to five days (Ibn Taghri Bardi, 1992), and in some cases death occurs within three days even "some die almost immediately or in the same days" (Al-Maqrizi, 1971), without disease progress and this type of plagues is called the black plagues and which spares nobody and most plagues that occurred in Egypt during the Mameluke were of this type, and in some rare cases the plague was of the medium type (Ibn-Taghr-iBardi, 1993), and here the illness takes a while and the patient may recover and most people susceptible to the plague disease as affirmed by the historical sources were children, women Mamelukes, slaves and foreigners (Ibn-Iyas, 1984).

The plague was a fast spreading disease that used to spread through rodents such as mice, it afflicts man and beast. Al-Maqrizi affirms that the great plague or what was known as the black death that spread through most parts of the world in 749 hegira/1348 AD spread through strong wind so "the winds carried the foul and the worst, so as it passed through a country or are and land and as soon as it was smelled by man or beast which meant almost immediate death in the same hour" and he says in another parts: "the cause of death with them is a wind that passes over the sea and as it is smelled by man it led to falling in other words death" (Al-Maqrizi, 1971).

And we infer from the account of Al-Maqrizi about the plagues disease which mentions an increase in body temperature, and vomiting blood and that in addition to other bodily symptoms, and it is mentioned that the patients had an (abscess in the body) which as soon as it is touched by hand which led instant death" (Al-Maqrizi, 1971).

And sometimes there shows on the body what is known as Al-kobbah "gland like an abscess" so Al-Maqrizi mentioned through his account of the plague events in the year 749 Hegira/ 1348 that a female worker went to bath a woman so after talking her clothes off, she passed her hand over the spot of the gland, then she shouted and fell dead, and there was found in her finger the abscess the size of a bean" (Al-Maqrizi, 1971), and this is a clear proof about how fast the disease spreads and how lethal the disease since the patient dies fast, and Al-Maqrizi confirms that that abscess had appeared even the in the afflicted animals with the disease, and he confirms that the fish lakes in Dumyat have their fish floating on the water and it had the abscess too and whenever fishing occurs" (Al-Maqrizi, 1971).

And some of the other symptoms of the plague were what was known as "blood spray" so the person feels temperature in the body, and feels nauseated so he or she spits blood, and dies afterwards and is followed in death by the whole people in the home one after another so that they all perish in one or two nights and no one needs syrup or medicines or doctors due to the speed of death (Al-Maqrizi, 1971).

And we infer from most historical sources that most plagues that hit Egypt used to start in the spring and becomes more intense at the beginning of the summer season except the great plague that hit Egypt in the year 833 Hegira /1429 AD where it occurred in the winter (Al-Maqrizi, 1971; Al-Aini, 1988).

Also the Egyptian society had also suffered from many epidemics that are represented by the numerous cases of fever cough and smallpox and most epidemics used to spread in Egypt during the winter, and spring seasons The direct reason for the spread of epidemics is that Egypt had southern blowing winds during the winter season, and of extreme coldness and high levels of moisture ,so cough and high fever prevails among most people (Ibn Hajer, 
1986), In some years during the spring season, Egypt was subject to stormy southerly winds of high temperature and know as al-miraysieh winds (called after the Merais village in southern Egypt), so acute disease occurs, especially disease characterized (Al-Maqrizi, 1971).

\subsection{The Plagues and Epidemics that Hit Egypt in the Mameluke Era}

The historical sources that were contemporary of the Mameluke state mentions that Egypt was hit by many plagues and epidemics, where hundreds of thousands of people had perished and led to the damage and demise of many of the cities and villages, and they have grave consequences on the total conditions of the country, and the most sever plagues that hit Egypt were those that occurred in the years 695 hegira /1295 AD, 749 hegira /1348 AD, 806 hegira /1403 AD. 819 hegira /1416 Ad, 822 hegira/1419 AD, 833 hegira /1429 AD 841 hegira /1437 AD, 897 hegira /1491, 903 hegira /1497. The plague that hit Egypt in the year 695 hegira /1295 AD caused the death of over two hundred thousand and the month of Safar and only in the city of Cairo alone a hundred eighty thousand people died" and I have found the condition of the population of Cairo as it turned to destruction and damage due to prompt and total disease and death" (Al-Aini, 1989; Ibn Kathir, 1987), and the plague of the year 749 hegira /1348 AD that led to the death of one third of people of Egypt, so death included all the areas of upper Egypt and in Cairo and in Egypt twenty thousand people died every day "and the dead were on the ground in the (Nile Delta) No one was to bury the dead" (Al-Maqrizi, 1971), and Al-Maqrizi added, and all places were filled with cries and so you will not find a house void of cries and you do not pass in street and not finding dead people and the coffins were colliding due to their abundance and the dead mix together due to high numbers of the dead, the city of Cairo alone lost during the months of Shaban and Ramadan over nine hundred thousand persons, and other areas outside Cairo lost people many times more than Cairo (Al-Maqrizi,1971).

Since the beginning of the ninth century hegira /fifteenth century AD many plagues spread in Egypt and in the year 806 hegira /1403 AD, Egypt was hit by a sever plague, and Al-Maqrizi described it by saying "and this year is the first of years of calamities that damaged the land Egypt, and most of its population perished and the conditions descended to low ebb and matters had reached a point of great disruption that signaled the destruction of the region of Egypt" (Al-Maqrizi,1971), and in the year 819 hegira /1416 AD the plague spread over the land of Egypt and especially the city of Egypt (Al-Fustian ) and Cairo and its environs "and everyone imagined that death is coming soon, due to the fast death of those afflicted with plague and the numerous persons dying in the same house and the ugly face of the country due to great sadness and sorrow ,and you will not find anybody not crying over a dead or busy with a patient and just small number of homes not having sorrow over a dead person" (Al-Maqrizi, 1971; Al-Sairafi, 1973), then plague hit again the land of Egypt in the year 822 hegira /1419 AD that caused the death of many persons especially children "and their death with acute diseases and not so many died within three days as most died in the same hour of catching the disease or in the same day" (Al-Maqrizi, 1971).

As for the plague that hit Egypt in the year 833 Hegira /1429 AD which caused the death of over three hundred thousand individuals Al-Sairafi says "and the imprudent says one thousand" (Al-Sairafi, 1973), and Al-Maqrizi describes the conditions of Egypt in that year by saying: "and there is no house which does not have a dead person or ill person and this epidemic made the surrounding ugly as never before except in rare cases, and a great number of homes has no one of their past occupants" (Al-Maqrizi, 1971), and he mentions in other place, and people caused congestion to get coffins and caskets, and coffins were carried on panels and cages and on the hands and people were unable to bury the dead, so they stayed in the cemeteries, and the diggers doing work all night and made many ditches where the dead were made to rest ...and people spent their nights seeking the people who do the washing the dead" the washers" and the ones who carry the coffins and also the coffins and you see the coffins of the dead in the streets as rows after rows of camels due to their vast numbers, and in continuous motion, and those were some of the horrors that we have witnessed" (Al-Maqrizi, 1971).

The plague that hit Egypt in the year 841 hegira /1437AD caused the death of over one hundred thousand individuals, most of whom were children slaves and especially female slaves to the point that homes had very small number of them (Al-Maqrizi, 1971), and as of the plague of 879 hegira /1491 AD which had caused the death of two hundred thousand individuals" it took people away as if it was a massive tide and made homes vacant of people "and the plague of 903 hegira /1497 AD caused the death of over two hundred thousand people" and caused the death of Mamelukes, slaves and children with extreme lethality (Ibn Iyas, 1984).

\subsection{The Social Impact of Plagues and Epidemics}

The plagues and epidemics had grave impact on the Egyptian society especially that those diseases had hit Egypt about fifty times, and led to the death of huge numbers of the population, and we infer from historical sources that human losses of Egypt exceeded two thousand individuals as we have noted earlier . 
It is no doubt that the huge human losses had led to the destruction of many cities and villages and as an example, we note here the plague of 695 hegira / 1295 AD that had a severe impact on Cairo and in that Al-Aini Says: "I have found the conditions of the people moving towards damage due to total illness and immediate death" (Al Aini, 1989), and the plague of 749 Hegira /1348 AD that led to the damage and destruction of many of the Cairo neighborhoods in full. Al-Maqrizi had described the condition of the city of Cairo by saying: "and many neighborhoods of (in Cairo) became without people and the neighborhood of birjwan has forty two vacant homes and the alleys, and the ways in them and the numerous home became empty and the belongings of its dwellers did not find any to take them" (Al-Maqrizi, 1971), Ibn Taghri Bardi says, "and Cairo is vacant and desolate and no passersby in its streets and where one walks from Bab Zweilleh to Bab Al-Nasr and find no body, and the dust and soil remained on the roads and the faces of people changed and places were filled with cries and you do not find a home without cries, and you do not pass in streets without many dead, and many alleys and neighborhoods were vacant of people and the belongings of its people find no one to take them, so if someone inherited something, then that may pass to a fourth and fifth person in one day" (Ibn Taghri Bardi, 1992). Most of the areas of upper Egypt became vacant of their inhabitants and became damaged, and the population of Assiut decreased from six thousand to one hundred sixteen individuals (Al-Maqrizi, 1971).

The plague that hit Egypt in the year 800 hegira /1397 AD led to the destruction of many cities and villages of Egypt and in that regard Al-Sairafi says "and most of the areas were vacant of their inhabitants, and large number of homes closed" (Al-Sairafi, 1973).

The plague of the year 808 hegira /1405 led to huge damage to many of the upper Egypt cities and villages "and there the plague spread with enormity until whole areas turned without inhabitants" (Al-Maqrizi, 1971), and the plague of the year 809 hegira /1406 AD perished most of the inhabitants of the cities of Egypt (Al-Fustat) and Cairo (Al-Maqrizi, 1971). The plague of the year 819hegira /1416 AD that damaged most of the cities and villages, where all imagined that death is coming soon due the speed of death of the person afflicted with plague and the numerous persons dying in the same house, and the frequency of the spread of the epidemic in all the territory of Egypt ...and the country took an ugly face due to the high level of sadness, and you will find only either crying person over a dead one or busy tending to a patient and only asmall number of homes in Cairo and Egypt and close areas where there was no grief over a dead person" (Al-Sairafi,1973).

The plague that hit Egypt in the year 833 hegira / 1429 Ad led to vacant homes from its inhabitants in most of the cities and villages or Egypt, where one hundred thousand of the population of Egypt and Cairo died and twice the number in lower Egypt (Note 1) and the Nile delta, Al-Maqrizi described that by saying "and there was no home without a dead person or a sick one and this epidemic was an ugly one except in rare cases and that many home vacant of all its past inhabitants, and that money left from the belongings from the dead were taken by persons not deserving to take them" (Al-Maqrizi, 1971).

And those calamities and disasters left intense psychological impact on the people and Al-Maqrizi mentions within his account of the impact of the plague of the year 833 Hegira /1429 Ad" and those calamities were of enormous intensity and very frightening, and people had feelings of fear, loneliness and intense fear which did not occur in the previous calamities in the older times" (Al-Aini, 1969).

As a result of the plague of the year 749hegira /1348 AD" the weddings ceased among people and no one heard that someone had a wedding or merry times during the epidemic and no heard singing" (Al-Maqrizi, 1971).

The prominent people of Egypt suffered due to the number of deaths among the slaves as" most of the persons who died were slaves" (Al Sairafi, 1973).

The high incidence of plagues and epidemics that hit the Egyptian society formed an impetus of social solidarity between the people, and sources cite that people of honor in the cities and villages took the initiative to wash the dead and prepare them for burial" and people did wash and wrap the dead with cloth to prepare them for burial as a charity free of charge" (Al-Maqrizi, 1971). After that they used to carry the dead on wood panels, stairs, and doors due to the high number of the dead, and Al-Maqrizi mentioned the heavy burden on those honorable people who dig the graves, and preparing the dead due to the high number of the dead. In this regard, he says within the events of the year 833 hegira $/ 1429$, and the high demand for coffins grave clothes, so the dead were carried on the panels, on cages and on the hands, and the people were unable to bury their dead and so they stayed with the dead in the cemeteries, and the diggers doing their work all night, and they made large ditches, where a one ditch contain a large number of the dead and people spend their night seeking the washers of the dead, and persons who carry the dead and coffins and the coffins of dead were seen in the streets as if they are rows and rows of camels due to their high number (Al-Maqrizi, 1971), and people were unable to bury the dead, so they carried them on the camels and threw them into the Nile river or the Mediterranean (Al-Sairafi, 1973). 
It is concluded from historical sources that honorable people played a vital role in easing those calamities and they divided the roles among themselves, a group washes and prepares the dead and others perform prayers on them in the mosques and then bury them (Ibn Taghri Bardi, 1992).

As for the rich, they spent a lot of their money on the poor, in this regard Al-Maqrizi says: "and the people having money were content to leave small amount for themselves and spent it on the poor" (Al-Maqrizi, 1971) and he also says and the people went to do the good, and everyone of them imagined that they are dead (Al-Maqrizi, 1971).

On another account there was also an increase in the obedience to Allah the almighty by worship and fasting, and increasing the alms and the true repentance for Allah the almighty in the hope that Allah the almighty may move away the calamity from them, so as a result of the plague that spread in the land of Egypt in the year 749 hegira /1348 AD people moved towards true repentance to Allah the almighty, and meeting in general in mosques especially in the cities of Egypt (AL-Fustat) and Cairo for prayers and calls to the almighty, and in that Ibn Taghri Bardi says: "people in general met in the mosques of the city of Egypt (Al-Fustat) and Cairo ( in the month of Ramadan), and the Egyptians went the prayer place of Kholan in Al-Qarafeh, and the also the reading of Al-Bukhari continued at Al-Azhar mosque and others for many days, and people calling by prayers to the almighty and people calling the religious call and worship to the almighty (Dua e-Qunoot) which is a very special, obedient and humble call to the Allah the almighty in their prayers" (Ibn Taghri Bardi, 1992).

Following the plague of the year 822 hegira $/ 1419$ AD, the people of Cairo were called upon by an order of the sultan Abu -Nasr Sheikh Al-Mahmoudi (815 Hegira /1412 AD-824 hegira /1421) to fast for three days and then go out to the desert outside Cairo near Qubbat Al-Nasr, for prayers and calls Allah the almighty to remove the calamity, so The sultan along with princes of the state and a large number of religious scholars and Sufi sheiks and the common people carrying with them the Holy Korans and flags to Qubbat Al-Nasr, and their voices grew louder calling Allah the almighty, Al-Maqrizi described that scene by saying: the Sultan descended from his horse ...and on his right and left the religious scholars and the caliph, and the people of knowledge, and around him so many people that only the almighty knows their number and he spread his hand and called to Allah the almighty while weeping immensely and he slaughtered with his own hand one hundred rams as sacrifice and oblation to Allah the almighty and ten cows, and two buffalos, and two lambs while he was crying and weeping, and his tears failing on his beard" (Al-Maqrizi, 1971), and the crowd continued in reverence and calling until heat became excessive , and they claimed that this is to explore the calamity and Allah after that moved the calamity away "(Al-Sairafi, 1973).

After the plague of the year 833 hegira $/ 1429$ people were called upon by the sultan Barsbay Al-Ashraf ( 824 hegira /1421 -842 hegira /1438) to fast for three days and the faithful true repentance to Allah the almighty and abandoning sins and injustices and on the fourth of Jumada Al-Oula, a large number of common people merger accompanying the Islamic chief justice Saleh Al- Balqini to the desert outside Bab Al-Nasr and prayed and wept immensely to move away the calamity and on the fifteenth of Jumada Al-Akhera the sultan ordered the official who oversees the sultan's correspondence "Kateb Al-Ser Al-Sharif" (Note 2) to gather the names of persons from the nobles, and to give them lots of money, and ordered them to stay at Al-Azhar mosque after the Friday prayer to read the Koran and pray" and that the mosque was very full of people and they kept praying until the afternoon time came and the forty nobles ascended to the roof of mosque and called for prayer and they prayed with the people the Asr prayer" the afternoon prayer and then they left (Al-Sairafi, 1973).

The sultan and the state officials resorted to come close to Allah the almighty by removing injustices and by promoting virtue and the prevention of vice, After the plague that spread all over Egypt in the year of 841 hegira /1437 AD, Sultan Barsbay Al-Ashraf gathered the judges and religious scholars and asked them about the sins that people committed and Allah the almighty punished them with plague, and they suggested that adultery became commonplace then plague appeared, so he tried to limit adultery by forbidding women to go from their home to the markets and streets, believing that by forbidding women to go out and that the epidemic will disappear" and it was called in Cairo and Egypt that no women shall pass in a street or market at all threatening those who leave their home with death, so most women did not leave homes, the young women, the older women and the female slaves and the viceroy (wali) of Cairo and some of the security officials were to follow the streets, and hitting whom they found of the women and became very strict in terms of deterrence and threats" (Al-Maqrizi, 1971).

But this decision had great impact on buying and selling in the markets, so the sale of many goods, clothes and perfumes stopped and earnings were low and the widows housewives and women with no custodian suffered a great harm, which promoted the sultan to allow elderly women and female slaves to go out to the markets to buy 
the needed items on the condition that they return to their homes before nightfall in order to reduce the degree of popular anger (Al-Sairafi, 1973).

And the sultan also ordered to lift injustices, so he ordered to release all prisoners, and closed all prisons as some way to be closer to Allah the almighty, but this decision had negative impact on the Egyptian society, which led to the spread of the stealing and looting and robbers and corrupt people increased in the country and "people declined to ask others to pay their dues" (Al-Maqrizi, 1971) and that led to the loss of rights.

\subsection{The Economic Impact of Plagues and Epidemics}

Historical sources mention that there was a severe disruption in the economic conditions of Egypt during the periods when plagues and epidemics spread and most of the activity of the state ceased and most arable lands were left without farming, and if farmed, there was no one to perform the harvest, because most of the farmers died.

In addition crafts were disrupted and earnings hit a low ebb, and trade suffered from recession, and as an example the plagues that spread over the Egypt in 749 Hegira /1348 AD led to the death of most farmers, so the land found no one to farm and harvest the fruits, all the orchards of the Nile delta were disrupted, and the orchards of the city of Dumyat were disrupted, and its trees dried, and the vast land of upper Egypt was empty and the wheels disrupted due to the death of most of its people. Al-Maqrizi describes the conditions of Egypt during that period by saying :"as the time of the harvest came when most of the farmers had died, and only few left and soldiers and their young men went for the harvest, and called whoever can harvest and take what they harvest, They did who could not help them to collect the harvest and they used their horses and their hands, and in most cases they were unable to harvest a lot of the crops so they left it" (Al-Maqrizi, 1971).

Most of the guarantees and sultanate matters ceased in the land Egypt, and the units of soldiers were moving more than one time in less than a week, In this regard Al-Maqrizi says: and the units were moving very frequently due to the very frequent death of soldiers, so the units pass from one to the other until taken by the seventh and eighth, so the units of soldiers the craftsmen like tailors and shoemakers and none took from his unit a full harvest, and many of them did not get anything, When the Nile days came and the time of farming came, there was a severe lack of men, so only half the land was farmed (Al-Maqrizi, 1971).

The death of farmers and abandoning the land without farming had a grave impact on the Egyptian society ,and Historical sources mention excessive costs in most of the years when the plague spread in Egypt, and in the first half of the ninth hegira century /the fifteenth century AD, the prices of grains and foodstuffs witnessed a sharp increase, so the Irdeb of wheat (Note 3 ) reached a price between four hundred fifty to one thousand dirhams, and the Irdeb of beans or barely exceeded three hundred twenty dirhams and the Irdeb of chickpeas was sold for five hundred dirhams, and the ratel (Note 4) "Egyptian pound "of mutton meat was sold for 12 dirhams, and the ratel of beef was sold for four and quarter of dirhams and the ratel of cheese for seven dirhams and the Qadah (Note 5)of rice for thirteen dirhams (Al-Maqrizi, 1971; Ibn Iyas, 1984).

The prices of grains and foodstuffs at the beginning of the Mameluke era were cheap, and in the year 676 hegira / 1276 AD grains each Irdeb for sold for two dirhams (Al-Aini, 1988).

Also medicines witnessed high price hikes due to high demand from patients especially sugar, watermelons and quince and purslane seeds, so " the prices of medications, and what patients needed reached many times of its prices" (Al-Maqrizi, 1971). With the arrival of the plague of 806 hegira /1403 Ad the demand for medicines increased, where its prices exceeded the amount and the Qadah of pumpkin pulp was sold for one hundred dirham, and weba (Note 6) purslane seeds was sold for seventy dirhams after it was two dirhams, and the Ratel of shirkhashal (a type of honeydew) was sold for one hundred thirty dirhams, and an ounce of sugar for eight dirhams, and a ratel of watermelon was sold of eight dirhams (Al-Maqrizi, 1971), Medications became so scarce that a qadah of purslane seeds was sold for eighty dirhams, and the price of a Qintar (Note 7) of Shirkhashal (a type of Honeydew) reached the price between one thousand four hundred dirhams to fifteen thousand dirhams (Al-Maqrizi, 1971), and three pomegranates were sold for sixty dirhams and a ratel of quince fluid was sold for one hundred thirty dirhams, and a ratel of pears was sold for twenty dirhams (Al-Maqrizi, 1971) due to the high demand for medicines by the patients.

Most of the factories were disrupted and Al-Tiraz and wikalah houses were closed due to the lack of craftsmen and most markets were disrupted and the prices of fabrics hit bottom low levels due to a very weak demand so it was sold with less than fifth of its price, and the prices of the books of knowledge reached lows due to the lack of demand, so a hamel (Note 8) of books was sold with the cheapest prices, " Most professions ceased, so they were no water carriers" people who carry water guards and slaves and most people with professions went to earn 
a living by preparing the dead, so some of them in front of the funerals due he scarcity of people doing recitation and another group were handling washing the dead and another group to carry them "so they achieved abundant wealth and the person reciting charges ten dirhams and the person porters six dirhams and the grave digger charges fifty dirhams for each grave, and Al-Maqrizi mentioned that most of those who worked in preparing the dead also died "so most did not enjoy their wealth and died (Al-Maqrizi, 1971).

As for to the disruption of businesses because people of professions left their professions, the state had forced them to go back to their work so it was called in Cairo that whom had a profession shall go back to the profession, and the price of a bucket water reached eight dirhams due to lack of men and camels and the price of grinding the Irdab of wheat reached fifteen dirhams (Al-Maqrizi, 1971).

Selling and buying were disrupted in most markets in Egypt in the year 749 Hegira /1348 AD. So, most of the sale of goods was disrupted, and clothes ad perfumes, and so the disruption and the recession and the halt of markets and low earnings were all added to the lives of people (Al-Maqrizi, 1971). "Gold and silver hit lows where a dinar was equal to fifteen dirhams after it was twenty, and most of crafts ceased" (Ibn Taghri Bardi, 1992), and the demand of most people focused on the wrapping material for the dead and coffins and what is needed for the dead like camphor (Al-Maqrizi, 1971).

Al-Maqrizi talked about the events of the of the year 841 hegira /1437 AD about the recession of the market due to the plague, and in that connections he says: "and one of the most things happening those that a man was calling to sell a Qibaa, (a kind of fabric) in many markets, and he did not find any buyer due to the recession in markets, and the slave market closed and the sale of the slaves stopped due to high level of death among them (Al-Maqrizi, 1971) and in most cases the Egypt's foreign trade would sometime cease in the times of plague (Al-Maqrzi, 1971).

On the other hand plagues had severe impact on the people of the desert(the Bedouins) and the plague of 749hegira/1348 AD caused the death of most the dwellers of the desert and their livestock (Al-Maqrizi, 1971) and the plague of the year 820 hegira / $1417 \mathrm{AD}$ destroyed most of the cattle of the upper Egypt, so Al-Maqrizi mentions about the events of that year "and in upper Egypt twenty four thousand lambs perished where it grazed in some pastures and totally perished" (Al- Maqrizi, 1971), and the plague of the year 841 hegira / 1437 AD caused loss of huge cows, sheep and livestock (Al-Maqrizi, 1971).

\section{The Conclusions}

The plagues are bacterial diseases that are lethal and fast spreading, and some of its symptoms are the increase in patient temperature, nausea, and severe fatigue, and most of the plagues that hit Egypt during the Mameluke era, were some of the most lethal and that also applies to the plague of black death, where it usually killed the afflicted person within one week of catching the disease.

The plagues had severe social impact on the populating and it led to the death of two thousand individuals, so hundreds of Egyptian villages and cities were damaged and the societal conditions were disrupted, and that was an impetus for social solidarity, and the true repentance towards Allah the almighty, and the increase of worship and alms giving in the hope that Allah the almighty will move the calamity away from them.

The plagues led to the disruption of the economic conditions of the society, where most lands were left without farming and most crafts and professions were disrupted, and earning hit lows in the markets and trade recession prevailed in general.

\section{References}

Al-Aini, B. M. (1987,1988, 1989). In M. A. Mohammad, Aqed Al-Jaman fi TarikhAhl Al-Zaman. Cairo: General Egyptian book organization.

Al-Aini, B. M. (1988). In M. A. Mohammad, Aqed Al-Jaman fi TarikhAhl Al-Zaman. Cairo: General Egyptian book organization.

Al-Dhahabi, S. M. A. (1985). In M. Abu Hajer, Al-Eber Fi Ma Ghaber (Part 4). Beirut: Dar Al-Kotob Al-Elmiah.

Al-Maqrizi, T. A. A. (1971). In A. Said Abdul-Fattah, Al-Solouk Li Maarafatdowal Al-Muluk (Part 4). Egypt: Dar Al-Kutub press.

Al-Maqrizi, T. A. A. (1988). Al-Mawa, ethWalI, tibarBithekr Al-KhotatWalAthar known as Al-Khotat (Part 4). Beirut: Dar Al-Kotob Al-Elmiah.

Al-Sairafi, A. D. (1973). In H. Hassan, Nuzhat Al-NufusWal-Abdan Fi Tawarikh Al-Zaman (Part 3). Egypt: Dar Al-Kutub press. 
Hinz, W. (1970). Measures and Weights of the Islamic World Amman. University of Jordan.

Ibn Hajer, A. A. (1986). Anbaa, Al-Qamar Bi Abnaa, Al Umor (2nd ed.). Beirut: Dar Al-KotobAl-Elmiah.

Ibn Iyas, M. A. (1984). In M. Z. Mohammad, Bada,e Al-Zohour Fi Waqae Al-Dohour. Cairo: General Egyptian book organization.

Ibn kathir, A. A. (1987). In A. Ahmad, Al-BidayahWalNihayah (2nd ed.). Beirut: Dar.

Ibn Manzour, J. M. M. (1900). Lisan Al-Arab. Beirut: Dar Sader.

Ibn Qayim, A. S. M. (2002). Al-Teb Al-Nabawi. Amman: Dar Al-Isra.

Ibn Taghri Bardi , J. A. A.(1992). Al-Nojoum Al-Zahara Fi Akhbar MulukMasr WalQahirah. Beirut: Dar Al-Kotob Al-Elmiah .

Ibn Taghri Bardi, J. A.A. (1990). In S. Mohamamd, Hawadeth Al-Duhur Fi Mada Al-AyamWalShuhur. Cairo: Dar Al-Kotob Al-Elmiah.

\section{Notes}

Note 1. Lower Egypt: includes all the Egyptian land that stretch on both banks of the Nile from the south of Cairo up to the southern border of Egypt .

Note 2. Kateb Al-Ser Al-Sharif: is the person or official who is responsible of the correspondence and letters of the sultan, Al-Maqrizi, Al-Mawa, ezwa El-I, tibarBitheker Al-Khotat WalAthar, Known as Al-Khotat, 4 partsDar Al-Kutub Al-Elmiah ,Beirut ,1996, part 3 , p 393.

Note 3. Al-Irdeb: an Egyptian weight measure for wheat, and equals $69.9 \mathrm{~kg}$, Walther Hinz measures and weights of the Islamic world, publications of the university of Jordan, Amman, 1970, pp. 94-95.

Note 4. Al-ratel and also pronounced ratl and the Egyptian ratel weights 144 dirham, and equals $37.5 \mathrm{~g}$, Walther Hinz, measures and weights of the Islamic world, pp. 30-31.

Note 5. Al-Qadah: an Egyptian weight measure and has two sizes, the small Qadah and every 16 of it was equal to webah, and every 48 if it was equal to irdeb, and the webah was equal to $12.68 \mathrm{~kg}$, Walther Hinz. measures and weights of the Islamic world, pp. 65-80 .

Note 6. Al-webah, an Egyptian weight measure and equals $12.168 \mathrm{~kg}$, Walther Hinz measures and weights of the Islamic world, p. 80.

Note 7. Al-Qintar: a weight measure and equals 100 ratel, and Al-ratel equals to $437.5 \mathrm{~g}$, Walther Hinz measures and weights of the Islamic world, pp. 40-44, 30-31 .

Note 8. Al-hamel: an Egyptian measure of weight and equals $135 \mathrm{~kg}$, Walther Hinz measures and weights of the Islamic world, p 27. Measures and weights of the Islamic world 